Article

\title{
Isolation, Chemical Profile and Antimalarial Activities of Bioactive Compounds from Rauvolfia caffra Sond
}

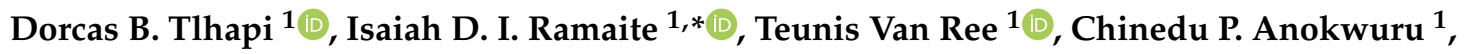 \\ Taglialatela-Scafati Orazio $^{2}$ (D) and Heinrich C. Hoppe ${ }^{3}$ (D) \\ 1 Department of Chemistry, University of Venda, Private Bag X5050, Thohoyandou 0950, South Africa; \\ dorcastlhapi@gmail.com (D.B.T.); Teuns.VanRee@univen.ac.za (T.v.R.); anokwuruchi@gmail.com (C.P.A.) \\ 2 Department of Pharmacy, University of Naples Federico II Via D. Montesano 49, 1-80131 Napoli, Italy; \\ scatagli@unina.it \\ 3 Department of Biochemistry and Microbiology, Rhodes University, Grahamstown 6140, South Africa; \\ H.Hoppe@ru.ac.za \\ * Correspondence: Isaiah.Ramaite@univen.ac.za; Tel.: +27(0)15-962-8262
}

Academic Editor: Isabel C.F.R. Ferreira

Received: 3 December 2018; Accepted: 20 December 2018; Published: 21 December 2018

\begin{abstract}
In this study, the chemical profile of a crude methanol extract of Rauvolfia caffra Sond was determined by ultra-performance liquid chromatography-mass spectrometry (UPLC-MS). Column chromatography and preparative thin layer chromatography were used to isolate three indole alkaloids (raucaffricine, $\mathrm{N}$-methylsarpagine and spegatrine) and one triterpenoid (lupeol). The antiplasmodial activity was determined using the parasite lactate dehydrogenase (pLDH) assay. The UPLC-MS profile of the crude extract reveals that the major constituents of $R$. caffra are raucaffricine $(m / z 513.2)$ and spegatrine $(m / z$ 352.2). Fraction 3 displayed the highest antiplasmodial activity with an $\mathrm{IC}_{50}$ of $6.533 \mu \mathrm{g} / \mathrm{mL}$. However, raucaffricine, isolated from the active fraction did not display any activity. The study identifies the major constituents of $R$. caffra and also demonstrates that the major constituents do not contribute to the antiplasmodial activity of $R$. caffra.
\end{abstract}

Keywords: bioactive compounds; Rauvolfia caffra Sond; antiplasmodial activity

\section{Introduction}

In many countries worldwide medicinal plants remain the dominant form of medicine for the treatment and prevention of a wide range of diseases. Medicinal plants used as alternative drugs are indicative of the vital role that plants play in many developing countries, and are also sources of novel plant-derived constituents that could be leads for treatment of malaria and other diseases. Malaria is a major public health problem in the world, responsible for the death of millions, particularly in sub-Saharan Africa [1,2]. Today, the control of malaria has become gradually more complex due to the spread of drug-resistant parasites [3,4]. The WHO estimated that globally, about $80 \%$ of people with malaria live in rural areas [5]. In Africa, 22 million new cases of malaria are reported every year and about $8.6 \%$ deaths occur in the region due to malaria $[2,6]$.

Treatment, management, and control of malaria are still a challenge to the medical community and safer, cheaper and more accessible alternatives are needed to efficiently limit the problem of this ailment [7]. Furthermore, the use of natural products for the treatment of malaria is becoming well-known due to the lesser side effects, accessibility and cost efficiency in comparison with conservative synthetic drugs. However, the number of plants with potential anti-malarial activities is limited and many of the purported anti-malarial properties have not been proven scientifically. Moreover, modes of action and active principles from most of these natural products are still unknown [8-16]. 
Rauvolfia caffra Sond is a plant species belonging to the family Apocynaceae [17]. R. caffra has been used widely for treatment of various conditions such as fever, swellings, abscesses, hepatitis, pneumonia, measles, skin lesions or itching rashes, cough, toothaches, sexually transmitted diseases, swollen legs, severe abdominal pains, abdominal disorders and wounds [18-21]. However, to the best of our knowledge, no in vivo or in vitro studies of potential applications of $R$. caffra in the treatment of these diseases have been reported. More generally, Rauvolfia species are commonly used in the treatment of malaria, diabetes, coughs, gastrointestinal disturbances, skin infections, hypertension, diarrhoea, dysentery, scabies, worm infections, parasitic and microbial infections. The ethnomedicinal uses make it one of the most important medicinal plants used in the suppression of skin diseases and opportunistic infections in HIV/AIDS patients in South Africa [22-26]. R. caffra Sond is rich in indole alkaloids, many of which have been isolated and identified $[27,28]$. The roots and stem bark extract possess high concentrations of reserpine, ajmaline and ajmalicine, which are known as antihypertensive and anti-inflammatory agents $[29,30]$. Furthermore, the extracts and derived alkaloids possess high antimicrobial activity due to the inhibition of certain redox pathways and other chemical processes in the bacterium cell [31]. These alkaloids also possess biological activities, such as antimalarial, antitumor and antidiabetic activity $[29,30]$.

$R$. caffra also contains saponins, which have a wide range of biological actions, including antimicrobial, antiviral, antioxidant and cytotoxic properties [32]. Rauvolfia caffra has been reported to contain secondary metabolites that have medicinal and economic value. However, not much is known about the biological activities of the isolated compounds from $R$. caffra. Moreover, many of the reports on the biological activities have been limited to crude extracts. Against this backdrop, we decided to isolate compounds from the stem bark and evaluate their antimalarial activity. The UPLC-MS profile indicated that raucaffricine is the major compound, but it was not active despite good activity of the fraction from which it was isolated. This means that the major compound does not contribute to the antiplasmodial activity. Our results confirm the reported antiplasmodial activity of the crude methanol extracts from Rauvolfia caffra [29]. However, isolated compounds from this plant have not yet been studied for their antiplasmodial activity. Therefore, this study is the first survey to detect significant antiplasmodial activity of $R$. caffra.

\section{Results and Discussion}

\subsection{Chemical Profile}

The chemical profile (Figure S1) of the crude extract was obtained by ultra-performance liquid chromatography mass spectrometry (UPLC-MS). Two major peaks with molecular ions $m / z 513.2$ (5.21) and $\mathrm{m} / z 301.1$ were observed in the crude extract. The peak with the molecular ion $\mathrm{m} / z 513.2$ was identified as raucaffricine, whereas the molecular ion $m / z 301.1$ was not identified due to the fact that the compound was lost during column fractionation. The chromatogram illustrates that raucaffricine is a major constituent of $R$. caffra stem bark. The chemical profile of fraction $\mathrm{F}_{3}$ (Figure S2) revealed three major constituents with the molecular ions $m / z 327.2, m / z 513.2$ and $m / z 349.2$, where raucaffricine, with the molecular ion $m / z 513.2$ (5.18) was found to be the major constituent of Fraction $\mathrm{F}_{3}$. The compounds with molecular ions $m / z 327.2$ and $m / z 349.2$ could not be isolated from Fraction $\mathrm{F}_{3}$. Furthermore, the chemical profile of Fraction $\mathrm{F}_{5}$ (Figure S3) revealed two major constituents, with the molecular ions $m / z 325.2$ and $m / z 335.1$, respectively, where the molecular ion $m / z 325.2$ was identified as that of spegatrine, whereas the compound with molecular ion $m / z 335.1$ was not isolated. Spegatrine with molecular ion $m / z 325.2$ was identified as a major constituent of fraction $\mathrm{F}_{5}$ but not a major constituent of the crude extract.

\subsection{Isolation and Purification of Compounds}

The crude methanol extract was subjected to column chromatography using silica gel to obtain five fractions $\left(\mathrm{F}_{1-5}\right)$. Lupeol (1, Figure 1$)$ was isolated as a white powder from a polar fraction $\left(\mathrm{F}_{1}\right)$ by 
repeated silica gel and reversed phase chromatography. A combination of nuclear magnetic resonance (1D- and 2D-NMR), infrared spectroscopy (IR) and high resolution mass spectrometric (HRMS) analysis was used for the structural elucidation of isolated compounds. Lupeol has the potential to act as an anti-inflammatory, anti-arthritic, anti-microbial, anti-poliferative and anti-protozoal [33]. Raucaffricine (2) was isolated as a brown amorphous solid from Fraction $\mathrm{F}_{3}(0.5 \mathrm{~g})$ after purification by semi-preparative HPLC. Fraction $\mathrm{F}_{4}$ was subjected to preparative TLC (reversed phase) to yield $\mathrm{N}$-methylsarpagine (3), a brown amorphous solid, and Fraction $\mathrm{F}_{5}$ was purified using semi-preparative HPLC to yield spegatrine (4), a brown amorphous solid. According to a literature survey, the biological activities of raucaffricine, $N$-methylsarpagine and spegatrine have never been evaluated. Therefore, that makes our study the first to test their biological activities.

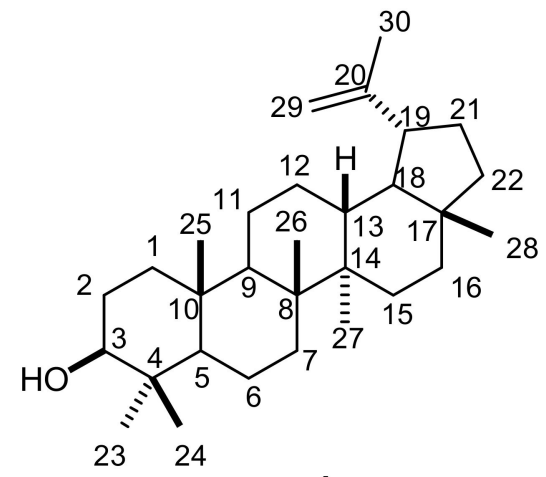

1

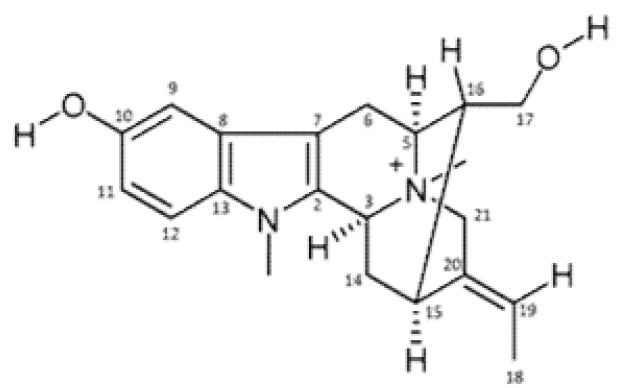

3

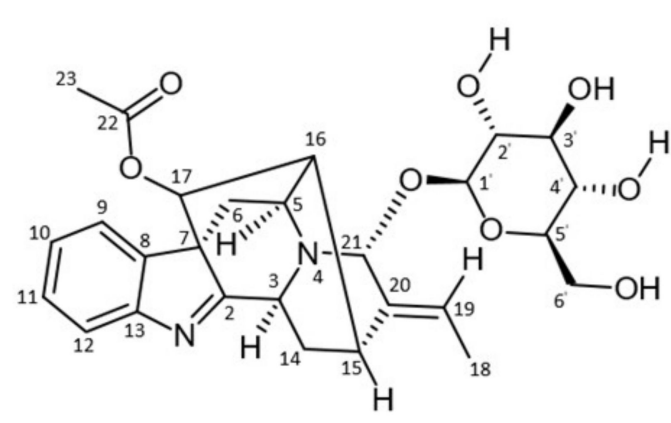

2

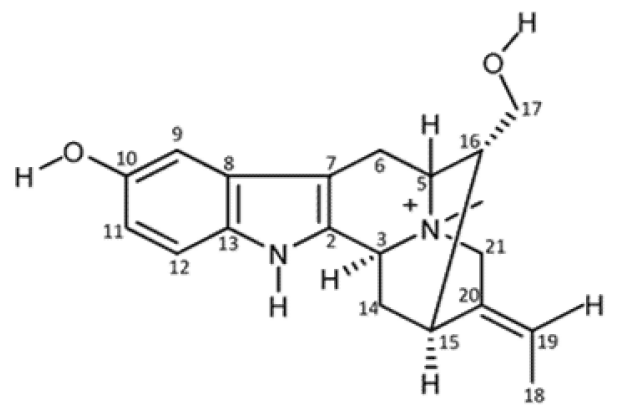

4

Figure 1. Isolated triterpenoid $\mathbf{1}$ and indole alkaloids 2-4.

The IR spectrum of lupeol (1) had a band corresponding to hydroxyl $\left(3000 \mathrm{~cm}^{-1}, \mathrm{O}-\mathrm{H}\right)$, and ${ }^{13} \mathrm{C}-\mathrm{NMR}$ results revealed the presence of 30 carbon signals. The ${ }^{1} \mathrm{H}-\mathrm{NMR}$ spectrum revealed the presence of six tertiary methyl protons at $\delta_{\mathrm{H}} 0.77 \mathrm{ppm}(3 \mathrm{H}, \mathrm{s}), \delta_{\mathrm{H}} 0.86 \mathrm{ppm}(3 \mathrm{H}, \mathrm{s}), \delta_{\mathrm{H}} 0.97 \mathrm{ppm}(3 \mathrm{H}, \mathrm{s})$, $\delta_{\mathrm{H}} 1.0 \mathrm{ppm}(3 \mathrm{H}, \mathrm{s}), \delta_{\mathrm{H}} 1.04 \mathrm{ppm}(3 \mathrm{H}, \mathrm{s})$ and $\delta_{\mathrm{H}} 1.70 \mathrm{ppm}(3 \mathrm{H}, \mathrm{s})$, corresponding to protons at positions $24,25,27,23,26$ and 30, respectively. A multiplet of one proton at $\delta_{\mathrm{H}} 2.38 \mathrm{ppm}(1 \mathrm{H}, \mathrm{m})$ assigned to $19-\mathrm{H}$ is characteristic of lupeol. The $3-\mathrm{H}$ proton displayed a multiplet at $\delta_{\mathrm{H}} 3.18 \mathrm{ppm}(1 \mathrm{H}, \mathrm{m})$ while a pair of broad singlets at $\delta_{\mathrm{H}} 4.7 \mathrm{ppm}(1 \mathrm{H}, \mathrm{s})$ and $\delta_{\mathrm{H}} 4.6 \mathrm{ppm}(1 \mathrm{H}, \mathrm{s})$ was indicative of olefinic protons at (29a-H and 29b-H). These assignments are in good agreement with the structure of lupeol (1).

Raucaffricine (2) exhibited a $[\mathrm{M}]^{+}$ion peak at $m / z 513.2237$ which matched the molecular formula $\mathrm{C}_{27} \mathrm{H}_{32} \mathrm{~N}_{2} \mathrm{O}_{8}$. The IR showed characteristic absorption frequencies at 3312.90, 2942.44 and $2831.65 \mathrm{~cm}^{-1}$ typical of the $\mathrm{O}-\mathrm{H}, \mathrm{C}-\mathrm{H}$ and $\mathrm{C}-\mathrm{H}$ bond vibrations, respectively. This was supported by the appearance of 27 carbon signals in its ${ }^{13} \mathrm{C}$-NMR spectrum, including six quaternary carbons, fifteen methines, four methylenes and two methyl groups at $\delta 21.32(\mathrm{Q}, \mathrm{C}-23)$ and $13.28(\mathrm{Q}, \mathrm{C}-18)$, respectively. The ${ }^{1} \mathrm{H}-\mathrm{NMR}$ spectrum showed an ortho-disubstituted aromatic ring with $\delta_{\mathrm{H}} 7.57$ to $7.2 \mathrm{ppm}$, which included two sets of doublets at $\delta_{\mathrm{H}} 7.55$ and $7.49 \mathrm{ppm}$ corresponding to protons at positions 9 and 12, a doublet of doublets at $\delta_{\mathrm{H}} 7.39 \mathrm{ppm}$ corresponding to a proton at position 10 and 
another doublet of doublets at $\delta_{\mathrm{H}} 7.23 \mathrm{ppm}$ corresponding to a proton at position 11 . The spectrum also showed the existence of an ethylidene group with a doublet at $\delta_{\mathrm{H}} 1.67 \mathrm{ppm}$ assigned to position 18 and a quartet at $\delta_{\mathrm{H}} 5.65 \mathrm{ppm}$ assigned to a proton at position 19. The ${ }^{1} \mathrm{H}-\mathrm{NMR}$ also revealed several other important features, including one methyl signal at $\delta_{\mathrm{H}} 2.16$ (s) corresponding to $\mathrm{OCOCH}_{3}$ and three methylene signals at $\delta_{\mathrm{H}} 4.42 \mathrm{ppm}, \delta_{\mathrm{H}} 1.87$ and $\delta_{\mathrm{H}} 1.77 \mathrm{ppm}$, and $\delta_{\mathrm{H}} 2.68$ and $\delta_{\mathrm{H}} 1.45 \mathrm{ppm}$, corresponding to $6^{\prime}-\mathrm{H}, 14-\mathrm{H}(\alpha$ and $\beta)$, and $6-\mathrm{H}(\beta$ and $\alpha)$, respectively. Moreover, a glucopyranosyl moiety was indicated by the signal of the anomeric proton at $\delta_{\mathrm{H}} 5.03\left(1 \mathrm{H}, \mathrm{d}, J=4.4 \mathrm{~Hz}, 1^{\prime}-\mathrm{H}\right)$ and in agreement with carbon signals at $\delta_{\mathrm{C}} 99.32\left(\mathrm{CH}, \mathrm{C}-1^{\prime}\right), 77.48\left(\mathrm{CH}, \mathrm{C}-3^{\prime}, \mathrm{C}-5^{\prime}\right), 74.26\left(\mathrm{CH}, \mathrm{C}-2^{\prime}\right)$, $70.58\left(\mathrm{CH}, \mathrm{C}-4^{\prime}\right)$ and $61.56\left(\mathrm{CH}_{2}, \mathrm{C}-6^{\prime}\right)$. The complete assignment of the ${ }^{1} \mathrm{H}-\mathrm{NMR}$ and ${ }^{13} \mathrm{C}-\mathrm{NMR}$ chemical shifts was done using 2D-NMR (COSY, HSQC and HMBC) spectroscopic techniques. These results enabled us to confirm the ${ }^{1} \mathrm{H}-\mathrm{NMR}$ and ${ }^{13} \mathrm{C}-\mathrm{NMR}$ chemical attributions of raucaffricine as previously reported [34].

The ${ }^{13} \mathrm{C}$-NMR of $\mathrm{N}$-methylsarpagine (3) showed 21 non-equivalent carbon signals. The ${ }^{1} \mathrm{H}-\mathrm{NMR}$ showed the presence of signals of three aromatic protons which included a doublet at $\delta_{\mathrm{H}} 7.11 \mathrm{ppm}$ $(1 \mathrm{H}, \mathrm{d}, J=8.6 \mathrm{~Hz})$, corresponding to a proton at position 12, another doublet at $\delta_{\mathrm{H}} 6.77 \mathrm{ppm}(1 \mathrm{H}, \mathrm{d}$, $J=2.0 \mathrm{~Hz})$ corresponding to a proton at position 9 and a doublet of doublets at $\delta_{\mathrm{H}} 6.68 \mathrm{ppm}(1 \mathrm{H}, \mathrm{dd}$, $J=22 . \mathrm{Hz}$ and $J=8.9 \mathrm{~Hz}$ ) corresponding to a proton at position 11 . The ${ }^{1} \mathrm{H}-\mathrm{NMR}$ also showed the existence of an ethylidene group with a doublet at $\delta_{\mathrm{H}} 1.63 \mathrm{ppm}$ assigned to position 18 and a quartet at $\delta_{\mathrm{H}} 5.59 \mathrm{ppm}$ assigned to a proton at position 19. The ${ }^{1} \mathrm{H}-\mathrm{NMR}$ also displayed an exchangeable hydroxyl proton at $\delta_{\mathrm{H}} 1.82 \mathrm{ppm}$, attached to $\mathrm{C}-10\left(\delta_{\mathrm{C}} 150.91\right)$ and two methyl groups corresponding to $\mathrm{N}_{1}$-Me at $\delta_{\mathrm{H}} 3.28 \mathrm{ppm}$ and $\mathrm{N}^{+}{ }_{4}$-Me at $\delta_{\mathrm{H}} 3.0 \mathrm{ppm}$. Total assignment was done by a close examination of the 1D-NMR ( ${ }^{1} \mathrm{H}-\mathrm{NMR}$ and $\left.{ }^{13} \mathrm{C}-\mathrm{NMR}\right), 2 \mathrm{D}-\mathrm{NMR}$ (COSY, HSQC and HMBC), UPLC-MS and literature data.

Spegatrine (4) revealed a $[\mathrm{M}+\mathrm{H}]^{+}$ion peak at $m / z 325.1912$ in its HRMS spectrum, suggesting the molecular formula $\mathrm{C}_{20} \mathrm{H}_{25} \mathrm{~N}_{2} \mathrm{O}_{2}{ }^{+}$. The ${ }^{13} \mathrm{C}-\mathrm{NMR}$ displayed 20 non-equivalent carbon signals, which was consistent with the HRMS result. The ${ }^{1} \mathrm{H}-\mathrm{NMR}$ showed an active hydroxyl proton at $\delta$ $1.97 \mathrm{ppm}$, attached to $\mathrm{C}-10\left(\delta_{\mathrm{C}} 150.93\right)$. The ${ }^{1} \mathrm{H}-\mathrm{NMR}$ was further characterized by a doublet at $\delta_{\mathrm{H}}$ $7.24 \mathrm{ppm}(1 \mathrm{H}, \mathrm{d}, J=8.8 \mathrm{~Hz})$, corresponding to a proton at position 12 , another doublet at $\delta_{\mathrm{H}} 6.90 \mathrm{ppm}$ $(1 \mathrm{H}, \mathrm{d}, J=2.0 \mathrm{~Hz})$ corresponding to a proton at position 9 and a doublet of doublets at $\delta_{\mathrm{H}} 6.78 \mathrm{ppm}$ $(2 \mathrm{H}, \mathrm{dd}, J=2 \mathrm{~Hz}$ and $J=2.4 \mathrm{~Hz})$ corresponding to a proton at position 11. Furthermore, the ${ }^{1} \mathrm{H}-\mathrm{NMR}$ showed an ethylidene group at $\delta_{\mathrm{H}} 1.74 \mathrm{ppm}(3 \mathrm{H}, \mathrm{d}, J=6.8 \mathrm{~Hz})$ associated with position 18 and a quartet at $\delta_{\mathrm{H}} 5.68 \mathrm{ppm}(1 \mathrm{H}, \mathrm{q}, J=6.8 \mathrm{~Hz})$ assigned to a proton at position 19. A N ${ }^{+}$-Me group at $\delta_{\mathrm{H}}$ $3.12 \mathrm{ppm}$ (s) which is a strong electron withdrawing group let the $21-\mathrm{H}$ protons appear at $\delta_{\mathrm{H}} 4.45 \mathrm{ppm}$ $(1 \mathrm{H}, \mathrm{d} \mathrm{AB}, J=15.6 \mathrm{~Hz})$ and at $\delta_{\mathrm{H}} 4.23 \mathrm{ppm}(1 \mathrm{H}, \mathrm{d} \mathrm{AB}, J=15.6 \mathrm{~Hz})$, respectively. Another signal shifted downfield was found at $\delta_{\mathrm{H}} 3.58 \mathrm{ppm}(1 \mathrm{H}, \mathrm{d}, J=7.6 \mathrm{~Hz})$ corresponding to two protons at $\mathrm{C}-17$ $\left(\delta_{C} 62.40\right)$. This condition may be due to the presence of a hydroxyl group attached to $C-17\left(\delta_{C} 62.40\right)$. Total assignment was done by a close examination of the 1D-NMR $\left({ }^{1} \mathrm{H}-\mathrm{NMR}\right.$ and $\left.{ }^{13} \mathrm{C}-\mathrm{NMR}\right), 2 \mathrm{D}-\mathrm{NMR}$ (COSY, HSQC and HMBC), UPLC-MS and literature data.

\subsection{Antiplasmodial Activity}

The highest antiplasmodial activity was found in fraction $\mathrm{F}_{3}$ with a viability of $4.149 \pm 6.979 \%$ (Figure 2) and $\mathrm{IC}_{50}$ value of $6.533 \mu \mathrm{g} / \mathrm{mL}$. The reference drug chloroquine showed an $\mathrm{IC}_{50}$ value of $0.032 \mu \mathrm{g} / \mathrm{mL}$, and was higher in activity than $\mathrm{F}_{3}$. The major compound raucaffricine, which was isolated from $\mathrm{F}_{3}$ was not active. This result shows that the major constituent does not contribute to the antiplasmodial activity of $R$. caffra. Spegatrine also did not display any activity.

As shown in Figure 3, Fraction $F_{3}$ at a concentration $250 \mu \mathrm{g} / \mathrm{mL}$ decreased the viability of Plasmodium falciparum $(4.149 \pm 6.979 \%)$ with an $\mathrm{IC}_{50}$ value of $6.533 \mu \mathrm{g} / \mathrm{mL}$, whereas the reference drug chloroquine showed an $\mathrm{IC}_{50}$ value of $0.032 \mu \mathrm{g} / \mathrm{mL}$. 


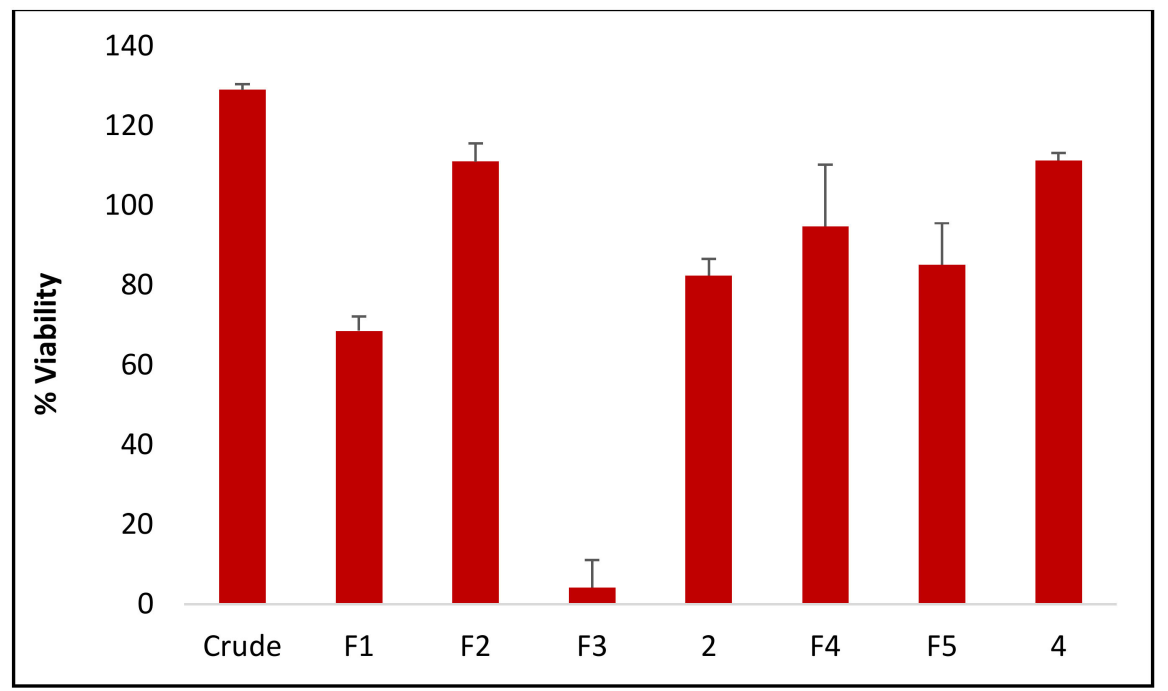

Figure 2. Antimalarial activity of crude, fractions, raucaffricine (2) and spegatrine (4) expressed as \% parasite viability $\pm \mathrm{SD}$.

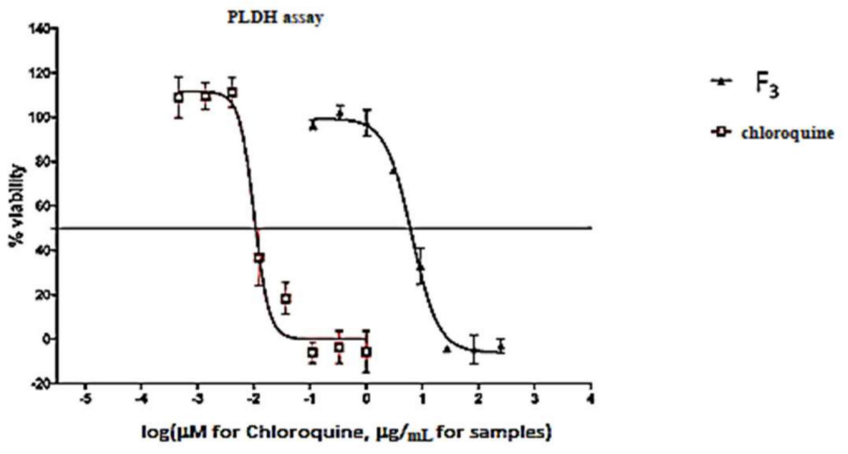

Figure 3. Dose-response curve for antimalarial assay.

\section{Materials and Methods}

\subsection{General Experimental Procedure}

All chemicals used were analytical grade purchased from Sigma-Aldrich (Darmstadt, Germany). Silica gel $(0.063-0.2 \mathrm{~mm})$ or Sephadex LH20 was used as stationary phases and solvent mixtures described below were used as mobile phase in the chromatographic separations. Thin layer chromatography plates packed with silica gel (normal or reversed phase), were used to locate major components of the fractions.

\subsubsection{High-Resolution Mass Spectrometry}

A Waters Synapt G2 Quadrupole time-of-flight (QTOF) mass spectrometer (MS) connected to a Waters Acquity ultra-performance liquid chromatograph (UPLC) (Waters, Milford, MA, USA) was used for direct injection high resolution mass spectrometric analysis. $1 \mu \mathrm{L}$ of sample was injected into a stream of $60 \%$ acetonitrile $/ 40 \% 0.1 \%$ formic acid in water. This conveyed the sample directly to the QTOF mass spectrometer where data was acquired using both positive and negative electrospray ionisation. The following MS settings were used: cone voltage of $15 \mathrm{~V}$, desolvation temperature of $275{ }^{\circ} \mathrm{C}$, desolvation gas at $650 \mathrm{~L} / \mathrm{h}$, and the rest of the MS settings optimized for best resolution and sensitivity. 


\subsubsection{Infrared Spectroscopy}

ATR Infrared (IR) spectra were recorded on an Alpha FTIR spectrometer (Bruker, Fällanden, Switzerland).

\subsubsection{NMR Spectroscopy}

${ }^{1} \mathrm{H}$ - and ${ }^{13} \mathrm{C}$-nuclear magnetic resonance (NMR) spectra were recorded at $400 \mathrm{MHz}$ and $100 \mathrm{MHz}$, respectively, with an Avance 400 spectrometer (Bruker) using residual undeuterated solvent as the internal standard.

\subsubsection{Liquid Chromatography-Mass Spectrometry (LCMS) Analysis}

The instrumentation used for ultra-performance liquid chromatography MS (UPLC-MS) was identical to that described above, except for the inclusion of a Waters BEH $\mathrm{C}_{18}, 2.1 \times 100 \mathrm{~mm}, 1.7 \mu \mathrm{m}$ column into the flow stream. This facilitated separation of compounds prior to data acquisition using a photodiode array detector (PDA), followed by the QTOF MS where data was acquired by scanning from $\mathrm{m} / z 150$ to $1500 \mathrm{~m} / z$ in resolution mode as well as in MSE mode. In MSE mode two channels of MS data were acquired, one at a low collision energy $(4 \mathrm{~V})$ and the second using a collision energy ramp $(40-100 \mathrm{~V})$ to obtain fragmentation data as well. Leucine enkephalin was used as lock mass (reference mass) for accurate mass determination and the instrument was calibrated with sodium formate. An injection volume of $3 \mu \mathrm{L}$ was used and the mobile phase consisted of $0.1 \%$ formic acid (solvent A) and acetonitrile containing $0.1 \%$ formic acid as solvent $\mathrm{B}$.

\subsection{Plant Collection and Preparation}

The stem bark of Rauvolfia caffra Sond was collected at the University of Venda Campus (Thohoyandou, Limpopo, South Africa) in January 2016. Botanical identification was provided by Prof. Tshisikhawe, a botanist in the Department of Botany at the University of Venda, and a voucher specimen (BD 001) was deposited. The plant samples were air-dried for two months and the dry samples were ground to fine powder using an industrial blender (mill).

\subsection{Extraction of Plant Materials}

About $1.7 \mathrm{~kg}$ ground stems of $R$. caffra were soaked with $2 \mathrm{~L}$ methanol for $48 \mathrm{~h}$ at room temperature. The methanol extract was filtered, and then concentrated using a rotary evaporator to obtain $49.2 \mathrm{~g}$ of dried extracts. The crude methanol extract $(49.2 \mathrm{~g})$ was subjected to column chromatography over silica gel.

The extract was eluted initially with hexane and the polarity was gradually increased with ethyl acetate and finally methanol, yielding 17 fractions. Fractions with similar TLC profile were combined and concentrated to dryness on a rotary evaporator giving a total of 8 fractions coded as $\mathrm{F}_{\mathrm{A}}-\mathrm{F}_{\mathrm{H}} \cdot \mathrm{F}_{\mathrm{A}}$ was obtained with hexane/ethyl acetate (70:30); $\mathrm{F}_{\mathrm{B}}, \mathrm{F}_{\mathrm{C}}$ were obtained with hexane/ethyl acetate (30:70); $\mathrm{F}_{\mathrm{D}}$ was obtained with ethyl acetate $(100 \%) ; \mathrm{F}_{\mathrm{E}}, \mathrm{F}_{\mathrm{F}}$ were obtained with ethyl acetate/methanol (70:30); and $\mathrm{F}_{\mathrm{G}}, \mathrm{F}_{\mathrm{H}}$ were obtained with ethyl acetate/methanol (30:70). The collected fractions were monitored on TLC plates.

\subsection{Isolation and Purification of Compounds}

Fractions $\mathrm{F}_{\mathrm{B}}, \mathrm{F}_{\mathrm{E}}, \mathrm{F}_{\mathrm{F}}$ and $\mathrm{F}_{\mathrm{G}}$ were further fractionated using column chromatography since they contained a large amount of material compared to fractions $\mathrm{F}_{\mathrm{A}}, \mathrm{F}_{\mathrm{C}}, \mathrm{F}_{\mathrm{D}}$ and $\mathrm{F}_{\mathrm{H}}$.

Fraction $\mathrm{F}_{\mathrm{B}}(1.42 \mathrm{~g})$ was subjected to Sephadex LH-20 column chromatography; the column was eluted with $\mathrm{CH}_{2} \mathrm{Cl}_{2} / \mathrm{MeOH}$ (50:50) followed by an increasing gradient of $\mathrm{CH}_{2} \mathrm{Cl}_{2} / \mathrm{MeOH}$ (up to 10:90) to obtain $\mathrm{F}_{1}(1 \mathrm{~g})$. Fraction $\mathrm{F}_{\mathrm{E}}(4 \mathrm{~g})$ was subjected to silica gel column chromatography; the column was eluted using $\mathrm{CH}_{2} \mathrm{Cl}_{2} / \mathrm{MeOH}$ (50:50) followed by an increasing gradient of $\mathrm{CH}_{2} \mathrm{Cl}_{2} / \mathrm{MeOH}$ (up to 10:90) to obtain 2 subfractions, $F_{2}(1.51 \mathrm{~g})$ and $F_{3}(1.55 \mathrm{~g})$. Fraction $F_{F}(4 \mathrm{~g})$ was also subjected to 
silica gel column chromatography and the column was eluted using $n-\mathrm{C}_{6} \mathrm{H}_{12} / \mathrm{EtOAc}$ (50:50) followed by an increasing gradient of $n-\mathrm{C}_{6} \mathrm{H}_{12} /$ EtOAc (up to 30:70) to obtain 1 subfraction, $\mathrm{F}_{4}$ ( $3 \mathrm{~g}$ ). Fraction $\mathrm{F}_{\mathrm{G}}$ (5.6 g) was subjected to Sephadex LH-20 column chromatography; the column was eluted using $\mathrm{CH}_{2} \mathrm{Cl}_{2} / \mathrm{MeOH}$ (50:50) followed by an increasing gradient of $\mathrm{CH}_{2} \mathrm{Cl}_{2} / \mathrm{MeOH}$ (up to 10:90) to obtain $\mathrm{F}_{5}(5 \mathrm{~g})$. The collected fractions were monitored on TLC plates. The thin layer chromatograms were developed in a solvent system of ethyl acetate/methanol/water (EMW 81:11:8). A natural product staining solution $(1 \mathrm{~g}$ methanolic diphenylboric acid, $100 \mathrm{~mL}$ methanol, $5 \mathrm{~mL}$ PEG 400 and $95 \mathrm{~mL}$ ethanol) was used to visualize compounds on a TLC plate.

$\mathrm{F}_{1}(0.5 \mathrm{~g})$ was subjected to preparative TLC (normal phase) to obtain compound $\mathbf{1}(0.230 \mathrm{~g})$. Fraction $\mathrm{F}_{2}(0.5 \mathrm{~g})$ was also subjected to preparative TLC (reversed phase) to obtain fraction $\mathrm{F}_{2 \mathrm{a}}(0.2102 \mathrm{~g})$. Fraction $\mathrm{F}_{3}(0.5 \mathrm{~g})$ was further purified using semi-preparative HPLC to yield compound $2(0.019 \mathrm{~g})$. Fraction $\mathrm{F}_{4}$ $(0.5 \mathrm{~g})$ was also subjected to preparative TLC (reversed phase) to obtain compound $3(0.1238 \mathrm{~g}) . \mathrm{F}_{5}(1 \mathrm{~g})$ was further purified using semi-preparative HPLC to obtain compound $4(0.086 \mathrm{~g})$.

Lupeol (1): IR: $3000 \mathrm{~cm}^{-1}(\mathrm{O}-\mathrm{H}) .{ }^{1} \mathrm{H}-\mathrm{NMR}\left(400 \mathrm{MHz}, \mathrm{CD}_{3} \mathrm{OD}\right): \delta_{\mathrm{H}} 4.7(1 \mathrm{H}, \mathrm{s}, 29 \mathrm{a}-\mathrm{H}), 4.6(1 \mathrm{H}, \mathrm{s}, 29 \mathrm{~b}-\mathrm{H})$, $3.18(1 \mathrm{H}, \mathrm{m}, 3-\mathrm{H}), 2.38(1 \mathrm{H}, \mathrm{m}, 19-\mathrm{H}), 1.91(1 \mathrm{H}, \mathrm{m}, 21-\mathrm{H}), 1.70(3 \mathrm{H}, \mathrm{s}, 30-\mathrm{H}), 1.60(1 \mathrm{H}, \mathrm{m}, 2-\mathrm{H}), 1.39(1 \mathrm{H}$, m, 18-H), $1.30(1 \mathrm{H}, \mathrm{m}, 9-\mathrm{H}), 1.04(3 \mathrm{H}, \mathrm{s}, 26-\mathrm{H}), 1.0(3 \mathrm{H}, \mathrm{s}, 23-\mathrm{H}), 0.97(3 \mathrm{H}, \mathrm{s}, 27-\mathrm{H}), 0.86(3 \mathrm{H}, \mathrm{s}, 25-\mathrm{H})$, $0.77(3 \mathrm{H}, \mathrm{s}, 24-\mathrm{H})$ ppm. ${ }^{13} \mathrm{C}-\mathrm{NMR}\left(\mathrm{CD}_{3} \mathrm{OD}\right): \delta_{\mathrm{C}} 150.95$ (C-20), 108.54 (C-29), 78.27 (C-3), 55.48 (C-5), 50.64 (C-9), 49.16 (C-18), 42.17 (C-14), 40.53 (C-8), 38.67 (C-4), 38.54 (C-1), 38.17 (C-13), 37.00 (C-10), 36.91 (C-16), 34.21 (C-7), 30.43 (C-21), 29.52 (C-23), 29.27 (C-2), 27.19 (C-15), 25.54 (C-12), 22.79 (C-11), 20.70 (C-30), 18.17 (C-6), 18.03 (C-28), 15.32 (C-26), 14.69 (C-24), 13.67 (C-27) ppm.

Raucaffricine (2): IR: $v_{\mathrm{O}-\mathrm{H}}$ at $3421.5 \mathrm{~cm}^{-1}(\mathrm{O}-\mathrm{H})$ and $v_{\mathrm{C}=\mathrm{O}}$ at $1662.0 \mathrm{~cm}^{-1}(\mathrm{C}=\mathrm{O}) .{ }^{1} \mathrm{H}-\mathrm{NMR}(400 \mathrm{MHz}$, DMSO- $\left.d_{6}\right): \delta_{\mathrm{H}} 7.55(1 \mathrm{H}, \mathrm{d}, J=7.6 \mathrm{~Hz}, 9-\mathrm{H}), 7.49(1 \mathrm{H}, \mathrm{d}, J=7.2 \mathrm{~Hz}, 12-\mathrm{H}), 7.39(1 \mathrm{H}, \mathrm{dd}, J=7.6 \mathrm{~Hz}$ and $J=7.6 \mathrm{~Hz}, 10-\mathrm{H}), 7.23(1 \mathrm{H}, \mathrm{dd}, J=7.2 \mathrm{~Hz}$ and $J=7.6 \mathrm{~Hz}, 11-\mathrm{H}), 5.65(1 \mathrm{H}, \mathrm{q}, J=6.8 \mathrm{~Hz}, 19-\mathrm{H}), 5.17$ $(1 \mathrm{H}, \mathrm{s}, 21-\mathrm{H}), 5.03\left(1 \mathrm{H}, \mathrm{d}, J=4.4 \mathrm{~Hz}, 1^{\prime}-\mathrm{H}\right), 4.57(1 \mathrm{H}, \mathrm{s}, 17-\mathrm{H}), 4.42(2 \mathrm{H}, \mathrm{dd}, J=7.6 \mathrm{~Hz}$ and $J=8.8 \mathrm{~Hz}$, $\left.6^{\prime}-\mathrm{H}\right), 3.9-3.6\left(1 \mathrm{H}, \mathrm{m}, 5^{\prime}-\mathrm{H}\right), 3.18(1 \mathrm{H}, \mathrm{dd}, J=5.6 \mathrm{~Hz}$ and $J=6 \mathrm{~Hz}, 5-\mathrm{H}), 3.08(1 \mathrm{H}, \mathrm{m}, 15-\mathrm{H}), 2.68(1 \mathrm{H}$, $\mathrm{dd}, J=4.8 \mathrm{~Hz}$ and $\left.4.4 \mathrm{~Hz}, 6-\mathrm{H}_{\beta}\right), 2.34(1 \mathrm{H}, \mathrm{dd}, J=6$ and $J=6.4 \mathrm{~Hz}, 16-\mathrm{H}), 2.16\left(3 \mathrm{H}, \mathrm{s}, \mathrm{OCOCH}_{3}\right), 1.87$ $\left(1 \mathrm{H}, \mathrm{dd}, J=4 \mathrm{~Hz}\right.$ and $\left.J=12 \mathrm{~Hz}, 14-\mathrm{H}_{\alpha}\right), 1.77\left(1 \mathrm{H}, \mathrm{dd}, J=4.8 \mathrm{~Hz}\right.$ and $\left.J=4.8 \mathrm{~Hz}, 14-\mathrm{H}_{\beta}\right), 1.67(3 \mathrm{H}, \mathrm{d}$, $\left.J=11.6 \mathrm{~Hz}, 18-\mathrm{CH}_{3}\right), 1.45\left(1 \mathrm{H}, \mathrm{d}, J=6.8 \mathrm{~Hz}, 6-\mathrm{H}_{\alpha}\right) \mathrm{ppm} .{ }^{13} \mathrm{C}-\mathrm{NMR}\left(\mathrm{DMSO}-d_{6}\right): \delta_{\mathrm{C}} 184.42(\mathrm{C}-2), 170.13$ (C-22), 156.86 (C-13), 137.94 (C-20), 137.09 (C-8), 127.06 (C-11), 125.81 (C-10), 124.29 (C-9), 122.76 (C-19), $120.85(\mathrm{C}-12), 99.32\left(\mathrm{C}-1^{\prime}\right), 88.22(\mathrm{C}-21), 77.48\left(\mathrm{C}-3^{\prime}, 5^{\prime}\right), 77.21(\mathrm{C}-17), 74.26\left(\mathrm{C}-2^{\prime}\right), 70.58\left(\mathrm{C}-4^{\prime}\right), 65.19(\mathrm{C}-7)$, 61.56 (C-6'), 55.24 (C-5), 50.45 (C-3), 48.49 (C-16), 37.32 (C-6), 27.47 (C-15), 24.67 (C-14), 21.32 (C-23), 13.28 (C-18) ppm. HRMS [M] ${ }^{+}: m / z$ 513.2241; calcd. for $\mathrm{C}_{27} \mathrm{H}_{32} \mathrm{~N}_{2} \mathrm{O}_{8}$ : 513.2237.

N-Methylsarpagine (3): IR: $3312.90(\mathrm{O}-\mathrm{H}), 2942.44(\mathrm{C}-\mathrm{H})$ and $2831.65 \mathrm{~cm}^{-1}(\mathrm{C}-\mathrm{H}) .{ }^{1} \mathrm{H}-\mathrm{NMR}(400 \mathrm{MHz}$, $\left.\mathrm{CD}_{3} \mathrm{OD}\right): \delta_{\mathrm{H}} 7.11(1 \mathrm{H}, \mathrm{d}, J=8.6 \mathrm{~Hz}, 12-\mathrm{H}), 6.77(1 \mathrm{H}, \mathrm{d}, J=2.0 \mathrm{~Hz}, 9-\mathrm{H}), 6.68(1 \mathrm{H}, \mathrm{dd}, J=8.9,2.2 \mathrm{~Hz}$, $11-\mathrm{H}), 5.59(1 \mathrm{H}, \mathrm{q}, J=6.8 \mathrm{~Hz}, 19-\mathrm{H}), 4.41\left(1 \mathrm{H}, \mathrm{d} \mathrm{AB}, J=15.6 \mathrm{~Hz}, 21-\mathrm{H}_{\beta}\right), 4.16(1 \mathrm{H}, \mathrm{d} \mathrm{AB}, J=15.6 \mathrm{~Hz}$, $\left.21-\mathrm{H}_{\alpha}\right), 3.48(2 \mathrm{H}, \mathrm{d}, J=7.2 \mathrm{~Hz}, 17-\mathrm{H}), 3.28\left(3 \mathrm{H}, \mathrm{s}, \mathrm{N}-\mathrm{CH}_{3}\right), 3.15\left(1 \mathrm{H}, \mathrm{dd}, J=12.4,4.8 \mathrm{~Hz}, 6-\mathrm{H}_{\beta}\right), 3.0(3 \mathrm{H}$, $\left.\mathrm{s}, \mathrm{N}^{+}-\mathrm{CH}_{3}\right), 2.95(1 \mathrm{H}, \mathrm{dd}, J=2.0,10.4 \mathrm{~Hz}, 15-\mathrm{H}), 2.9\left(1 \mathrm{H}, \mathrm{d}, J=15.2 \mathrm{~Hz}, 6-\mathrm{H}_{\alpha}\right), 2.4(1 \mathrm{H}, \mathrm{dd}, J=11.6$, $10.8 \mathrm{~Hz}, 14-\mathrm{H} \alpha), 2.12-2.0\left(2 \mathrm{H}, \mathrm{m}, 16-\mathrm{H}+14-\mathrm{H}_{\beta}\right), 1.82(\mathrm{~s}, \mathrm{OH}), 1.63(3 \mathrm{H}, \mathrm{d}, J=6.7 \mathrm{~Hz}, 18-\mathrm{H}) \mathrm{ppm}$. ${ }^{13} \mathrm{C}-\mathrm{NMR}\left(\mathrm{CD}_{3} \mathrm{OD}\right): \delta_{\mathrm{C}} 150.91$ (C-10), 132.10 (C-20), 131.68 (C-13), 127.67 (C-8), $126.83(\mathrm{C}-2), 120.72$ (C-19), 112.34 (C-12), 111.75 (C-11), 102.14 (C-9), 99.77 (C-7), 65.45 (C-5), 64.39 (C-17), 62.40 (C-21), 61.07 (C-3), 43.63 (C-16), 32.01 (C-14), 26.01 (C-15), 23.87 (C-6), 11.57 (C-18) ppm.

Spegatrine (4): IR: $3352.1 \mathrm{~cm}^{-1}(\mathrm{O}-\mathrm{H})$ and $1638.8 \mathrm{~cm}^{-1}(\mathrm{~N}-\mathrm{H}) .{ }^{1} \mathrm{H}-\mathrm{NMR}\left(400 \mathrm{MHz}, \mathrm{CD}_{3} \mathrm{OD}\right): \delta_{\mathrm{H}} 7.24$ $(1 \mathrm{H}, \mathrm{d}, J=8.8 \mathrm{~Hz}, 12-\mathrm{H}), 6.90(1 \mathrm{H}, \mathrm{d}, J=2.0 \mathrm{~Hz}, 9-\mathrm{H}), 6.78(1 \mathrm{H}, \mathrm{dd}, J=2.2,8.8 \mathrm{~Hz}, 11-\mathrm{H}), 5.68(1 \mathrm{H}, \mathrm{q}$, $J=6.8 \mathrm{~Hz}, 19-\mathrm{H}), 4.45\left(1 \mathrm{H}, \mathrm{d} \mathrm{AB}, J=15.6 \mathrm{~Hz}, 21-\mathrm{H}_{\alpha}\right), 4.23\left(1 \mathrm{H}, \mathrm{d} \mathrm{AB}, J=15.6 \mathrm{~Hz}, 21-\mathrm{H}_{\beta}\right), 3.58(2 \mathrm{H}$, $\mathrm{d}, J=7.6 \mathrm{~Hz}, 17-\mathrm{H}), 3.27\left(1 \mathrm{H}, \mathrm{dd}, J=12.4,4.8 \mathrm{~Hz}, 6-\mathrm{H}_{\beta}\right), 3.15\left(3 \mathrm{H}, \mathrm{s}, \mathrm{N}^{+}-\mathrm{CH}_{3}\right), 3.12(1 \mathrm{H}, \mathrm{dd}, J=2.0$, $10.4 \mathrm{~Hz}, 15-\mathrm{H}), 3.04\left(1 \mathrm{H}, \mathrm{d}, J=17.2 \mathrm{~Hz}, 6-\mathrm{H}_{\alpha}\right), 2.54(1 \mathrm{H}, \mathrm{dd}, J=11.6,10.8 \mathrm{~Hz}, 14-\mathrm{H} \alpha), 2.23-2.13(2 \mathrm{H}, \mathrm{m}$, $\left.16-\mathrm{H}+14-\mathrm{H}_{\beta}\right), 1.97(\mathrm{~s}, \mathrm{OH}), 1.74(3 \mathrm{H}, \mathrm{d}, J=6.8 \mathrm{~Hz}, 18-\mathrm{H}) \mathrm{ppm} .{ }^{13} \mathrm{C}-\mathrm{NMR}\left(\mathrm{CD}_{3} \mathrm{OD}\right): \delta_{\mathrm{C}} 150.93(\mathrm{C}-10)$, 132.10 (C-20), 131.66 (C-13), 127.68 (C-8), 126.83 (C-2), 120.71 (C-19), 112.35 (C-12), 111.73 (C-11), 102.13 
(C-7), 99.77 (C-9), 65.46 (C-5), 64.38 (C-21), 62.40 (C-17), 61.08 (C-3), $46.67\left(\mathrm{~N}^{+}-\mathrm{CH}_{3}\right), 43.62$ (C-16), 32.00 (C-14), 26.01 (C-15), 23.87 (C-6), 11.56 (C-18) ppm. HRMS [M] ${ }^{+}: \mathrm{m} / z$ 325.1912; calcd. for $\mathrm{C}_{20} \mathrm{H}_{25} \mathrm{~N}_{2} \mathrm{O}_{2}{ }^{+}$: 325.1911.

\subsection{Antiplasmodial Activity}

Malaria parasites (Plasmodium falciparum chloroquine-sensitive strain 3D7, obtained from the Malaria Research and Reference Reagent Resource Center, Manassas, VA, USA) were maintained in RPMI 1640 medium containing $2 \mathrm{mM}$ L-glutamine and $25 \mathrm{mM}$ Hepes (Lonza Bioscience, Allendale, NJ, USA). The medium was further supplemented with 5\% Albumax II, $20 \mathrm{mM}$ glucose, $0.65 \mathrm{mM}$ hypoxanthine, $60 \mu \mathrm{g} / \mathrm{mL}$ gentamycin and $2-4 \%$ hematocrit human red blood cells. The parasites were cultured at $37{ }^{\circ} \mathrm{C}$ under an atmosphere of $5 \% \mathrm{CO}_{2}, 5 \% \mathrm{O}_{2}$ and $90 \% \mathrm{~N}_{2}$ in sealed T75 culture flasks. For screening compounds against malaria parasites, $20 \mu \mathrm{M}$ for pure compounds ( 2 and 4$)$ or $25 \mu \mathrm{g} / \mathrm{mL}$ of the crude extract and fractions $\mathrm{F}_{1}, \mathrm{~F}_{2}, \mathrm{~F}_{3}, \mathrm{~F}_{4}$ and $\mathrm{F}_{5}$ were added to parasite cultures ( $2 \%$ parasitaemia, $1 \%$ hematocrit) in 96-well plates and incubated for $48 \mathrm{~h}$ at $37^{\circ} \mathrm{C}$ in a sealed chamber suffused with the above gas mixture. After $48 \mathrm{~h}$ the plates were removed from the incubator and parasite levels in the individual wells determined using the parasite lactate dehydrogenase (pLDH) assay [35]. $20 \mu \mathrm{L}$ culture was removed from each well and mixed with $100 \mu \mathrm{L}$ Malstat solution (55 mM Tris, $0.22 \mathrm{M}$ L-lactic acid, $0.17 \mathrm{mM}$ acetylpyridine adenine dinucleotide [APAD], $0.2 \%[v / v]$ Triton X-100, $\mathrm{pH} 9.0$ ) and $25 \mu \mathrm{L}$ NBT/PES solution (1.96 mM nitrotetrazolium blue chloride, $0.24 \mathrm{mM}$ phenazine ethosulphate) in a fresh 96-well plate. After incubation for $30 \mathrm{~min}$, colour development was measured as absorbance at $620 \mathrm{~nm}\left(\mathrm{Abs}_{620}\right)$ in a Spectramax M3 plate reader (Molecular Dynamics Inc., Chatsworth, CA, USA). After subtracting background readings obtained from control wells (uninfected red blood cells), Abs ${ }_{620}$ values were converted to \% parasite viability relative to untreated control cultures. For dose-response analysis, the above procedure was repeated by incubating parasite cultures in 96-well plates with 3-fold serial dilutions of the crude extract, fractions $\left(\mathrm{F}_{1}, \mathrm{~F}_{2}, \mathrm{~F}_{3}, \mathrm{~F}_{4}\right.$ and $\left.\mathrm{F}_{5}\right)$ and compounds 2 and 4 . Log (compound concentration) was plotted against \% parasite viability and $\mathrm{IC}_{50}$ values calculated by non-linear regression using GraphPad Prism (GraphPad Software, San Diego, CA, USA). Chloroquine (an anti-malarial drug) was used as a positive control drug standard for antimalarial activity.

\section{Conclusions}

Four compounds were isolated from the stem bark methanol extract of $R$. caffra. Raucaffricine, a rare glycoalkaloid of the monoterpenoid indole class and spegatrine, an indole alkaloid isolated for the first time from Rauvolfia verticillata. This is the first report of the isolation of spegatrine from R. caffra. Lupeol, a pentacylic triterpenoid was previously isolated from various medicinal plants while $\mathrm{N}$-methylsarpagine, an indole alkaloid, was first isolated from Rauvolfia vomitoria. This is the first report of the isolation of lupeol and $\mathrm{N}$-methylsarpagine from the genus Rauvolfia and $R$. caffra species. The UPLC-MS chromatogram indicated that raucaffricine is a major alkaloid from $R$. caffra but did not contribute to the antiplasmodial activity of the fraction from which it was isolated.

Supplementary Materials: The supplementary materials are available online.

Author Contributions: D.B.T. performed the experiments. H.C.H. performed the biological tests. T.-S.O. assisted with the structure elucidation. D.B.T., I.D.I.R., T.v.R., C.P.A. designed the project and analysed the data. D.B.T., I.D.I.R., T.v.R., C.P.A. also provided the materials and reagents.

Funding: This research received no external funding.

Acknowledgments: This work was financially supported by the National Research Foundation, Sasol Inzalo and University of Venda RPC.

Conflicts of Interest: The authors declare no conflict of interest. 


\section{References}

1. Mboowa, G. Genetics of Sub-Saharan African Human Population: Implications for HIV/AIDS, Tuberculosis and Malaria. Int. J. Evol. Biol. 2014, 2014, 1-2. [CrossRef] [PubMed]

2. World Health Organisation. The World Malaria Report. World Health Organisation: Geneva, Switzerland, 2013.

3. Mojarrab, M.; Shiravand, A.; Delazar, A.; Afshar, H.F. Evaluation of in vitro antimalarial activity of different extracts of Artemisia aucheri Boiss and A. armeniaca Lam and fractions of the most potent extracts. Sci. World J. 2014, 2014, 1-6.

4. Chukuocha, U.M.; Nwakwuo, G.C.; Alinnor, L.C. Influence of maternal factors on neonatal malaria in South Eastern Nigeria. J. Dis. Global Health 2016, 7, 71-77.

5. Jigam, A.A.; Abdulrazaq, U.T.; Egbuta, M.N. In-vivo antimalarial and toxicological evaluation of Chrozophora senegalensis A. uss (Euphorbiaceae) extracts. J. Appl. Pharmacol. Sci. 2011, 1, 90-94.

6. World Health Organisation. The World Malaria Report. World Health Organisation: Geneva, Switzerland, 2014.

7. World Health Organisation. Guidelines for the Treatment of Malaria, 3rd Ed. ed; World Health Organisation: Geneva, Switzerland, 2015.

8. Schwikkard, S.; van Heerden, F.R. Antimalarial activity of plant metabolites. Nat. Prod. Rep. 2002, 19, 675-692. [CrossRef] [PubMed]

9. Saxena, S.; Pant, N.; Jain, D.C.; Bhakuni, R.S. Antimalarial agents from plant sources. Current Science 2003, 85, 1314-1329.

10. Frederich, M.; Tits, M.; Angenot, L. Potential antimalarial activity of indole alkaloids. Trans. R. Soc. Trop. Med. Hyg. 2008, 102, 11-19. [CrossRef]

11. Kaur, K.; Jain, M.; Kaur, T.; Jain, R. Antimalarials from nature. Bioorg. Med. Chem. 2009, 17, 3229-3256. [CrossRef]

12. Batista, R.; de Jesus Silva Júnior, A.; de Oliveira, A.B. Plant-derived antimalarial agents: New leads and efficient phytomedicines. Part II. Non alkaloidal natural products. Molecules 2009, 14, 3037-3072.

13. Bussmann, R.W.; Malca, G.; Glenn, A.; Sharon, D.; Nilsen, B.; Parris, B.; Dubose, D.; Ruiz, D.; Saleda, J.; Martinez, M.; et al. Toxicity of medicinal plants used in traditional medicine in Northern Peru. J. Ethnopharmacol. 2011, 137, 121-140. [CrossRef]

14. Fennell, C.W.; Lindsey, K.L.; McGaw, L.J.; Sparg, S.G.; Stafford, G.I.; Elgorashi, E.E.; Grace, O.M.; van Staden, J. Assessing African medicinal plants for efficacy and safety: Pharmacological screening and toxicology. J. Ethnopharmacol. 2004, 94, 205-217. [CrossRef] [PubMed]

15. Petrovska, B.B. Historical review of medicinal plants' ${ }^{\prime}$ usage. Pharmacogn. Rev. 2012, 6, 1-5. [CrossRef] [PubMed]

16. Rukunga, G.; Gathirwa, J.; Omar, S.; Muregi, F.; Muthaura, C.; Kirira, P.; Mungai, G.; Kofi-Tsekpo, W. Anti-plasmodial activity of the extracts of some Kenyan medicinal plants. J. Ethnopharmacol. 2009, 121, 282-285. [CrossRef] [PubMed]

17. Nkunya, M.H. Progress in the search for Antimalarials. In NAPRECA Monograph Series No.4.; NAPRECA: Addis Ababa, Ethiopia, 1992; Addis Ababa University.

18. Tshikalange, T.E.; Meyer, J.J.M.; Hussein, A.A. Antimicrobial activity, toxicity and the Isolation of a bioactive compound from plants used to treat sexually transmitted diseases. J. Ethnopharmacol. 2005, 96, 515-519. [CrossRef] [PubMed]

19. Schmelzer, G.H.; Gurib-Fakim, A. Plant Resources of Tropical Africa 11(1): Medicinal Plants 1; PROTA Foundation/ Backhuys: Leiden, The Netherlands, 2008; pp. 480-483.

20. Njau, E.A. An ethnobotanical study of medicinal plants used by the Maasai People of Manyara, Arusha-Tanzania. Master's Thesis, School of Graduate Studies. Addis Ababa University, Addis Ababa, Ethiopia, 2001. [CrossRef]

21. Bryant, A.T. Zulu Medicine and Medicine-Men, 2nd Ed. ed; Struik: Cape Town, South Africa, 1996.

22. Amole, O.O.; Onabanjo, A.C.; Agbaje, E.C. Effect of bark extract of Rauvolfia vomitoria (Afzel) in malaria. Parasitol. Internat. 1998, 47, 283-289.

23. Campbell, J.I.A.; Mortensen, A.; Mølgaard, P. Tissue lipid lowering effect of traditional Nigerian antidiabetic infusion of Rauvolfia vomitoria foliage and Citrus aurantium fruit. J. Ethnopharmacol. 2006, 104, 379-386. [CrossRef] [PubMed]

24. Pesewu, G.A.; Cutler, R.R.; Humber, D.P. Antibacterial activity of plants used in traditional medicines of Ghana with particular reference to MRSA. J. Ethnopharmacol. 2008, 116, 102-111. [CrossRef] [PubMed]

25. Oyedeji, L. Drugless Healing Secrets; Panse Press: Ibadan, Nigeria, 2007. 
26. McMillen, H. The adapting healer: Pioneering through shifting epidemiological and social cultural landscapes. Soc. Sci. Med. 2004, 59, 889-902. [CrossRef] [PubMed]

27. Malik, A.; Siddiqui, S. The subsidiary alkaloids of Rauwolfia vomitoria Afzuelia. Pak. J. Sci. Ind. Res. 1979, $22,121-123$.

28. Amer, M.M.; Court, W.E. Leaf alkaloids of Rauwolfia vomitoria. Phytochemistry 1980, 19, 1833-1836. [CrossRef]

29. Katič, M.; Kušan, E.; Prošek, M.; Bano, M. Quantitative densitometric determination of reserpine and ajmaline in Rauwolfia vomitoria by HPTLC. J. High Res. Chromatogr. 1980, 3, 149-150. [CrossRef]

30. Dewick, P.M. Medicinal natural products: A biosynthetic approach, 2nd Ed. ed; John Wiley \& Sons: New York, NY, USA, 2002.

31. Mazza, G.; Fukumoto, L.; Delaquis, P.; Girard, B.; Ewert, B. Anthocyanins, phenolics and color of Cabernet Franc, Merlot, and Pinot Noir wine from British Columbia. J. Agricul. Food Chem. 1999, 47, 4009-4017. [CrossRef]

32. Francis, G.; Kerem, Z.; Makkar, H.P.; Becker, K. The biological action of saponins in animal systems: A review. Brit. J. Nutri. 2002, 88, 587-605. [CrossRef] [PubMed]

33. Siddique, H.F.; Saleem, M. Beneficial health effects of lupeol triterpene: A review of preclinical studies. Life Sci. 2011, 88, 285-293. [CrossRef] [PubMed]

34. Khan, N.H.; Khan, M.A.; Siddiqui, S. Studies in the Alkaloids of Rauwolfia caffra Sonder. Part I. Isolation of Ajmalicine, Ajmaline, Raucaffrine and Three New Alkaloids: Raucaffricine, Raucaffriline and Raucaffridine. Pak. J. Sci. Ind. Res. 1965, 8, 23.

35. Makler, M.T.; Ries, J.M.; Williams, J.A.; Bancroft, J.E.; Piper, R.C.; Gibbins, B.L.; Hinrichs, D.J. Parasite lactate dehydrogenase as an assay for drug sensitivity. Am. J. Trop. Med. Hyg. 1993, 48, 739-741. [CrossRef] [PubMed]

Sample Availability: Not available.

(C) 2018 by the authors. Licensee MDPI, Basel, Switzerland. This article is an open access article distributed under the terms and conditions of the Creative Commons Attribution (CC BY) license (http://creativecommons.org/licenses/by/4.0/). 